\title{
INFLUENCE OF Spartina alterniflora INVASION STAGES ON MACROBENTHIC COMMUNITIES ON A TIDAL FLAT IN WENZHOU BAY, CHINA
}

\author{
Bao-Ming Ge $e^{1}$, Yi-Xin Bao ${ }^{2 *}$, Hong-Yi Cheng ${ }^{2}$, Dai-Zhen Zhang ${ }^{l}$ and Zhi-Yuan Hu${ }^{2}$ \\ ${ }^{1}$ Yancheng Teachers University - Jiangsu Provincial Key Laboratory of Coastal Wetland Bioresources and \\ Environmental Protection \\ (Kaifang Dadao 50, Yancheng, 224051 P. R. China) \\ ${ }^{2}$ Zhejiang Normal University - Institute of Ecology \\ (Yingbin Dadao 688, Jinhua, 321004 P. R. China) \\ *Correponding author: sky90@zjnu.cn
}

\begin{abstract}
A B S T R A C T
Many coastal habitats in eastern China are being substantially altered by the invasion of Spartina alterniflora. The species richness, density, Margalef's diversity index $(\mathrm{R})$ and Shannon's diversity index $\left(\mathrm{H}^{\prime}\right)$ of macrobenthic communities on a tidal flat in Wenzhou Bay, China, were analyzed with the factors of invasion stage and season, in 2007. A significant effect of invasion stage, season, and the interaction between them on communities was detected. The macrobenthic community was more complex in the patch of initial S. alterniflora invasion than in the patches of some other invasion stages. Macrobenthic communities were classified by cluster and ordination in accordance with the habitat character of the $S$. alterniflora invasion stage. Our research demonstrated that the $S$. alterniflora invasion stage affected the macrobenthic communities significantly. The results indicated that biodiversity increased in the initial stage of invasion (invasion age 1-2 years) and then decreased in the stage of invasion underway (invasion age 3-4 years) and in the stage of invasion completed (invasion age 5-6 years); this phenomenon was related to the change in the S. alterniflora canopy which accompanied the invasion stages.
\end{abstract}

\section{R ESUMO}

Muitos habitats costeiros vêm sendo alterados substancialmente pela invasão de Spartina alterniflora no leste da China. Em 2007, em uma planície de maré situada em Wenzhou Bay, foram analisadas riqueza de espécies, densidade e diversidade da macrofauna bêntica em relação a diferentes estágios da invasão da gramínea e à estação do ano. Para as medidas de diversidade foram usados os índices de Margalef (R) e de Shannon (H'). Foram detectados efeitos significativos do estágio de invasão e época do ano sobre a macrofauna. As comunidades macrofaunais foram mais complexas nas manchas onde a invasão de $S$. alterniflora estava no seu início, quando considerados os locais onde as manchas estavam em estágios mais avançados. Através das análises de agrupamento e ordenação as comunidades puderam ser classificadas pelo tipo de habitat formado em cada estágio de invasão da Spartina. Os resultados indicaram que a biodiversidade aumentou no estágio de invasão inicial (idade de invasão de 1 a 2 anos), mas diminuiu gradativamente com os estágios intermediário (idade de invasão de 3 a 4 anos) e completo (idade de invasão de 5 a 6 anos), mostrando assim o efeito deletério de S. alterniflora sobre a estrutura da macrofauna presente no local.

Descriptors: Biodiversity; Western Pacific coast ; Invasion; Benthic macrofauna; Ecosystem engineers.

Descritores: Biodiversidade, Costa Pacífica occidental, Invasão, Macrofauna bêntica, Espécies engenheiras. 


\section{INTRODUCTION}

In coastal wetlands, invasive plants often act as ecosystem engineers altering flow, light and sediments which, in their turn, can affect benthic animal communities (NEIRA et al., 2007). Here we define ecosystem engineers as species capable of creating, maintaining, modifying, or destroying the benthic habitat, thereby strongly influencing community composition and structure (JONES et al., 1994). In wetlands, when an invasive plant that is an ecosystem engineer colonizes a habitat, it can modify the community structure and the entire ecosystem by altering nutrient cycling, productivity, hydrology, particle flux and habitat availability (TALLEY; LEVIN, 2001; CROOKS, 2002). Genus Spartina (cordgrass) is readily identified as a key ecosystem engineer in salt marshes (PENNINGS; BERTNESS, 2001; BRUSATI; GROSHOLZ, 2006), and many species are known to be highly invasive (DAEHLER; STRONG, 1997) which could affect the benthic community significantly (HEDGE; KRIWOKEN, 2000; NEIRA et al., 2006; 2007). S. alterniflora is a perennial salt marsh grass native to the Atlantic and Gulf coasts of North America (SIMENSTAD; THOM, 1995) which has invaded the western coast of the Pacific extensively and influenced the native ecosystem, especially in China (WANG et al., 2006).

There are reports of evidence that $S$. alterniflora may out-compete native plants, threaten native ecosystems and coastal aquaculture, and cause decline in native species richness (NEIRA et al., 2005; LEVIN et al.,2006). In some marshes dominated by $S$. alterniflora, macrobenthic communities exhibit lower densities and fewer species relative to adjacent tidal flats (WANG et al., 2010). While some studies have shown that there was similar qualitative species composition of benthic communities in natural marshes and $S$. alterniflora constructed marshes, ranging from 6 to 24 years old, in South Carolina, natural marshes were not directly compared in these studies (ALPHIN; POSEY, 2000). Little research has so far been reported on the question as to how the macrobenthos came to be distributed in patches on a tidal flat with different $S$. alterniflora invasion stages (NEIRA et al., 2007).

The macrobenthic communities in patches of different $S$. alterniflora invasion stages on the tidal flat of eastern Lingkun Island, Wenzhou Bay, Zhejiang, China, were investigated during the various seasons of 2007. Greater biodiversity occurred in the high tidal zone of the study area, while lower biodiversity occurred in the low tidal zone; the structure of the macrobenthic community mostly affected by the tidal zone and seasonal effect factors was limited (BAO et al., 2007). The high tidal zone habitat can be divided into different patches in accordance with the various $S$. alterniflora invasion stages.

Here we address the question of how the $S$. alterniflora invasion stages influence macrobenthic distribution. The variation of macrobenthic communities in the patches characterized by different invasion stages of $S$. alterniflora was detected, and then multivariate statistical methods (cluster and ordination) were used to present the difference. This study can help reveal the ecological effects of the $S$. alterniflora invasion on the macrobenthos.

\section{Material And Methods}

$$
\text { Study Location and Sampling }
$$

Lingkun Island ( $\left.\mathrm{N} 27.95^{\circ}, \mathrm{E} 120.93^{\circ}\right)$ is located in the estuary of Oujiang River (Wenzhou Bay), Zhejiang Province, China. The average salinity of the seawater at the tidal flat is $16 \%$; the climate is subtropical; the tide type is informal semidiurnal with an average $4.5 \mathrm{~m}$ tidal range (LU et al., 2005; GE et al., 2011). The soft sediment is composed mainly of silt. $S$. alterniflora was introduced on the eastern tidal flat of Lingkun Island in 1989 (LI et al., 2009) and then, by 2007 , it had become the dominant plant of the upper and high tidal zones of the flat where this research project was undertaken.

Four kinds of patches of different S. alterniflora invasion stages, namely (1) no invasion, (2) initial invasion, (3) invasion underway and (4) invasion completed were selected in the high tidal zone, for the research. Then the area of the patches and canopy of $S$. alterniflora were graded to indicate the sequence of invasion stages (invasion age). Four patches of different invasion stages were selected in the high tidal zone of eastern Lingkun Island (Fig. 1) such that their environmental characteristics (e.g. climate, salinity) were similar. The patches were described as of:

No invasion (Habitat code: A), a bare, flat mud patch (area of about $10 \mathrm{~m}^{2}$ ) was selected.

Initial invasion (Habitat code: B), a flat mud patch with $S$. alterniflora standing, the plant covering varying between about $10 \%$ (in winter) and $30 \%$ (in summer), while the invasion age was of 1-2 years (area about $15 \mathrm{~m}^{2}$ ).

Invasion underway (Habitat code: $\mathrm{C}$ ), a flat mud patch with $S$. alterniflora standing, the plant covering varying between about $40 \%$ (in winter) and $70 \%$ (in summer), while the invasion age was of 2-4 years (area about $50 \mathrm{~m}^{2}$ ).

Invasion completed (Habitat code: D), a flat mud patch with $S$. alterniflora standing, the plant's covering varying between about $70 \%$ (in winter) and $100 \%$ (in summer), while the invasion age was 5-6 years (area larger than $100 \mathrm{~m}^{2}$ ). 


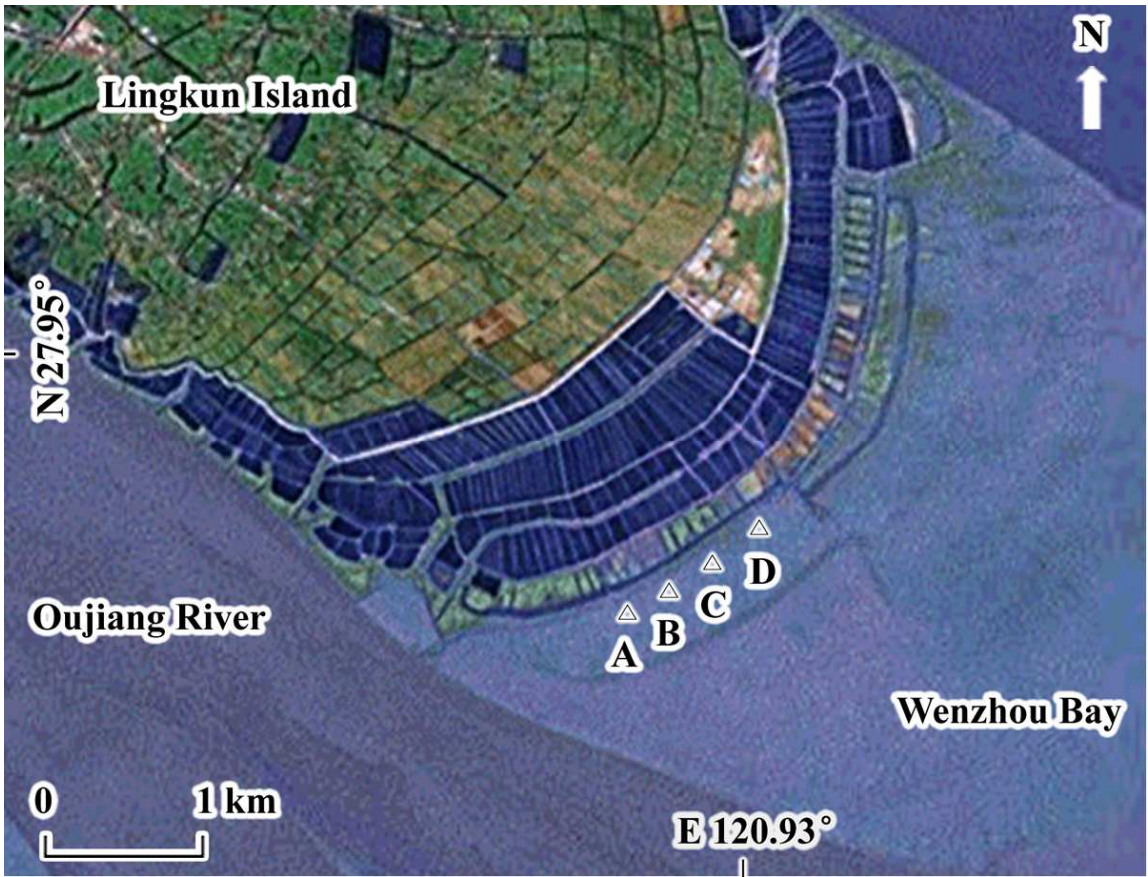

Fig. 1. The map of the selected patches with different $S$. alterniflora invasion stages (A: No invasion; B: Initial invasion; C: Invasion underway; D: Invasion completed).

Field sampling took place repeatedly in February (winter), May (spring), August (summer) and November (autumn) 2007. Then five replicates were taken randomly from each patch by using a 0.099 $\mathrm{m}^{2}(33 \mathrm{~cm} \times 30 \mathrm{~cm})$ stainless steel sampling box (depth of $20 \mathrm{~cm}$ ), the plants above the sediment were cleaned up before sampled. A total of 80 samples were processed for quantitative analysis. Macrobenthos were washed through a $1.0 \mathrm{~mm}$ mesh sieve on the spot, preserved in a neutral Formalin-Rose Bengal mixture and identified to the lowest possible taxonomic level and counted.

\section{Statistical Analysis}

The abundance species richness and biodiversity indices such as $R$ - Margalef's diversity index (1) and $H^{\prime}$ - Shannon's diversity index (2) were calculated for each sample. Two-way ANOVA analysis was used to determine differences in species richness, abundance and biodiversity indices by invasion stage, season and the interaction between them. Levene's test was used to determine equality of variance prior to using the two-way ANOVA. When a dataset did not pass Levene's test, the data was natural $\log$ transformed (CLEARY et al., 2008); in the study, the abundance and $H^{\prime}$ datasets were transformed.
Biodiversity indices followed:

- Margalef's diversity index: $R=(S-1) / \ln N$ (MARGALEF, 1957);

- Shannon's diversity index: $H^{\prime}=-\sum p_{i} \ln p_{i}$ (SHANNON; WEAVER, 1949);

- $p_{i}=$ proportion of individuals in a sample that belong to species $i$. $S=$ total number of species (species richness) encountered. $N=$ the number of individuals (abundance).

To detect the effect of $S$. alterniflora invasion stages in each season for abundance, species richness, $R$ and $H^{\prime}$, the one-way ANOVA was used. Prior to using the one-way ANOVA, Levene's test was employed to determine equality of variance, and then the Posthoc test [Student-Newman-Keuls (SNK) method when Levene's test passed; Dunnett's T3 (the Studentized maximum modulus) method when Levene's test did not pass] was used when any significant difference occurred (DUNNETT, 1980).

To present a panoramic view of the differences between the macrobenthic communities, the abundance of five replicate samples was accumulated as a new dataset. The classification (hierarchical cluster with Euclidean distance similarity matrix method) and ordination (non-metric Multi Dimensional Scaling, nMDS) were used in multivariate analysis and were employed for 
community structure analysis based on accumulated abundance data with 4 th root transformed (OLBERS et al., 2009; GOGINA et al., 2010). The classification and nMDS were based on the data on the composition of communities; they are the visualization technique that constructs a configuration of samples based on the distance (or similarity) matrix (CLARKE; WARWICK, 2001). Clustering was carried out by a hierarchical, agglomerative method using average linkage.

SPSS 16.0 (SPSS Inc.) and Microsoft Office Excel 2003 (Microsoft Inc.) were employed for statistical analysis.

\section{RESULT}

Communities Composition

A total of 21 species belonging to 4 phyla were recorded in the investigation, most of them were mollusks (10 species) and arthropods (8 species), while the Nemertina and Nematoda were not identified to species level (Table 1).

Test and Comparison
For species richness, abundance and $H^{\prime}$, the two-way ANOVA revealed a significant effect of invasion stage [abundance; $\mathrm{F}(3,64)=229.933, p<$ 0.001 ; species richness: $\mathrm{F}(3,64)=182.399, p<0.001$; $\left.H^{\prime}: \mathrm{F}(3,64)=194.932, p<0.001\right]$, season [abundance; $\mathrm{F}(3,64)=35.520, p<0.001$; species richness: $\mathrm{F}(3,64)$ $\left.=6.271, p=0.001 ; H^{\prime}: \mathrm{F}(3,64)=3.835, p=0.014\right]$ and interaction [abundance; $\mathrm{F}(9,64)=12.273, p<$ 0.001; species richness: $\mathrm{F}(9,64)=6.484, p<0.001$; $\left.H^{\prime}: \mathrm{F}(9,64)=6.253, p<0.001\right]$. While for $R$, the twoway ANOVA revealed a significant effect of invasion stage $[\mathrm{F}(3,64)=95.166, p<0.001]$ and interaction $[\mathrm{F}(9,64)=5.171, p<0.001]$, but there was no significant effect of season $[\mathrm{F}(3,64)=1.081, p=$ $0.363]$.

The macrobenthic communities in the patch with $S$. alterniflora initial invasion have the highest abundance, species richness and biodiversity indices, while in the patch with $S$. alterniflora invasion completed, the lowest biodiversity values occurred. The macrobenthic communities changed significantly in accordance with invasion stage, and the abundance, species richness, biodiversity indices decreased(Fig. 2; Table 2).

Table 1. Macrobenthic species in the patches with different $S$. alterniflora invasion stages.

\begin{tabular}{|c|c|c|c|c|}
\hline Phylum & Class & Family & Species & Invasion stage \\
\hline \multirow[t]{10}{*}{ Mollusca } & Gastropoda & Assimineidae & Assiminea brevicula & $\mathrm{ABCD}$ \\
\hline & & & A. latericera & $\mathrm{BCD}$ \\
\hline & & Potamididae & Cerithidea cingulata & $\mathrm{ABCD}$ \\
\hline & & & C. largillierti & $\mathrm{ABCD}$ \\
\hline & & Littorinidae & Littorina brevicula & $\mathrm{BCD}$ \\
\hline & & Atyidae & Bullacta exarata & $\mathrm{ABCD}$ \\
\hline & & Nassidae & Nassarius siquijorensis & $\mathrm{ABCD}$ \\
\hline & Lamellibranchia & Solenidae & Sinonovacula constricta & A \\
\hline & & Tellinidae & Moerella iridescens & $\mathrm{ABCD}$ \\
\hline & & Corbulidae & Potamocorbula ustulata & $\mathrm{ABC}$ \\
\hline \multirow[t]{8}{*}{ Arthropoda } & Crustacea & Grapsidae & Helice sheni & $\mathrm{BCD}$ \\
\hline & & & H. wuana & $\mathrm{ABCD}$ \\
\hline & & & Sesarma haematocheir & $\mathrm{BCD}$ \\
\hline & & & Macrophthalmus japonicus & $\mathrm{BCD}$ \\
\hline & & & Metopograpsus quadridentatus & $\mathrm{BCD}$ \\
\hline & & Ocypodidae & Uca arcuata & $\mathrm{BC}$ \\
\hline & & & Ilyoplaxsp. & $\mathrm{ABCD}$ \\
\hline & & Leucosiidae & Philyra pisum & A \\
\hline \multirow[t]{2}{*}{ Annelida } & Polychaeta & Glyceridae & Glycera chirori & $\mathrm{ABC}$ \\
\hline & & Nereidae & Nereis japonica & $\mathrm{ABCD}$ \\
\hline Chordata & Osteichthyes & Periphthalmidae & Scartelaos viridis & $\mathrm{ABCD}$ \\
\hline Nemertina & & & Not identified & $\mathrm{ABC}$ \\
\hline Nematoda & & & Not identified & $\mathrm{ABC}$ \\
\hline
\end{tabular}

A: No invasion; B: Initial invasion; C: Invasion underway; D: Invasion completed. 
Table 2. The one-way ANOVA on macrobenthic communities' characters (Mean $\pm \mathrm{SE}$ ) among patches with different $S$. alterniflora invasion stages in each season.

\begin{tabular}{clllll}
\hline \hline Season & Patches & Abundance & Species richness & \multicolumn{1}{c}{$\boldsymbol{H}^{\prime}$} & $2.04 \pm 0.07^{\mathrm{b}}$ \\
\hline Spring & A & $15.20 \pm 1.11^{\mathrm{b}}$ & $8.20 \pm 0.58^{\mathrm{b}}$ & $2.67 \pm 0.24^{\mathrm{b}}$ & $2.21 \pm 0.06^{\mathrm{bc}}$ \\
& B & $15.20 \pm 1.02^{\mathrm{b}}$ & $10.00 \pm 0.63^{\mathrm{c}}$ & $3.31 \pm 0.17^{\mathrm{c}}$ & $2.30 \pm 0.04^{\mathrm{c}}$ \\
& C & $16.60 \pm 0.51^{\mathrm{b}}$ & $10.80 \pm 0.37^{\mathrm{c}}$ & $3.49 \pm 0.11^{\mathrm{c}}$ & $1.22 \pm 0.07^{\mathrm{a}}$ \\
Summer & D & $5.20 \pm 0.37^{\mathrm{a}}$ & $3.60 \pm 0.24^{\mathrm{a}}$ & $3.11 \pm 0.06^{\mathrm{b}}$ & $2.18 \pm 0.54^{\mathrm{b}}$ \\
& A & $19.40 \pm 1.21^{\mathrm{b}}$ & $10.20 \pm 0.37^{\mathrm{b}}$ & $3.55 \pm 0.22^{\mathrm{b}}$ & $2.34 \pm 0.06^{\mathrm{b}}$ \\
& B & $27.60 \pm 0.98^{\mathrm{c}}$ & $12.80 \pm 0.80^{\mathrm{c}}$ & $3.18 \pm 0.11^{\mathrm{b}}$ & $2.15 \pm 0.02^{\mathrm{b}}$ \\
& C & $21.80 \pm 0.49^{\mathrm{b}}$ & $10.80 \pm 0.37^{\mathrm{b}}$ & $1.30 \pm 0.21^{\mathrm{a}}$ & $1.30 \pm 0.08^{\mathrm{a}}$ \\
& D & $5.40 \pm 0.40^{\mathrm{a}}$ & $3.20 \pm 0.37^{\mathrm{a}}$ & $3.09 \pm 0.12^{\mathrm{b}}$ & $2.17 \pm 0.04^{\mathrm{b}}$ \\
& A & $15.20 \pm 0.86^{\mathrm{b}}$ & $9.40 \pm 0.40^{\mathrm{b}}$ & $3.48 \pm 0.15^{\mathrm{c}}$ & $2.36 \pm 0.04^{\mathrm{c}}$ \\
& B & $22.40 \pm 0.75^{\mathrm{c}}$ & $11.80 \pm 0.37^{\mathrm{c}}$ & $2.90 \pm 0.17^{\mathrm{b}}$ & $2.07 \pm 0.06^{\mathrm{b}}$ \\
& C & $17.00 \pm 0.71^{\mathrm{b}}$ & $9.20 \pm 0.49^{\mathrm{b}}$ & $2.14 \pm 0.11^{\mathrm{a}}$ & $1.65 \pm 0.04^{\mathrm{a}}$ \\
& D & $8.80 \pm 0.80^{\mathrm{a}}$ & $5.60 \pm 0.24^{\mathrm{a}}$ & $2.61 \pm 0.12^{\mathrm{b}}$ & $2.01 \pm 0.05^{\mathrm{b}}$
\end{tabular}

A: No invasion, B: Initial invasion; C: Invasion underway; D: Invasion completed. Means with different super scripts in the same column (each season) are significantly different $(p<0.050)$.
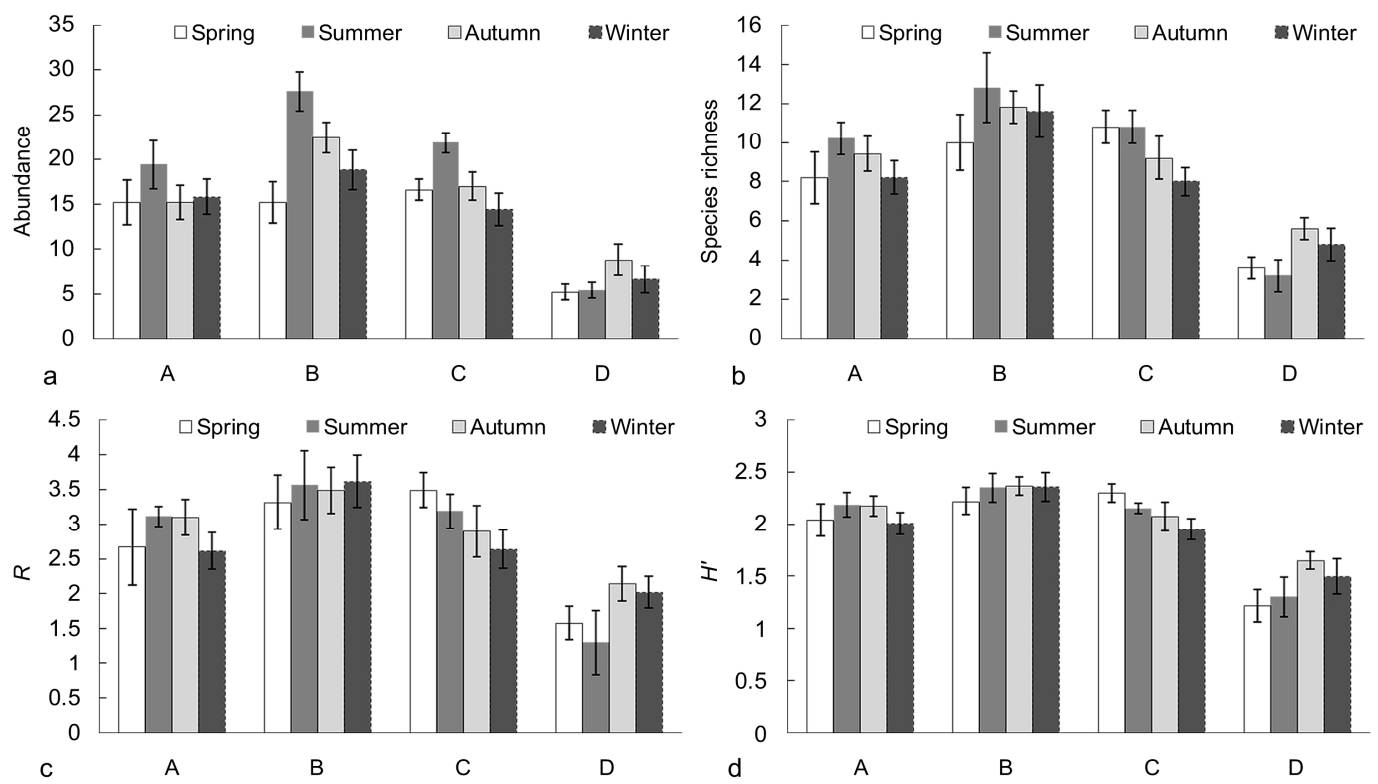

Fig. 2. The abundance (a), species richness (b), $R$ (c) and $H^{\prime}$ (d) values of macrobenthic communities of the patches with different $S$. alterniflora invasion stages (A: No invasion; B: Initial invasion; C: Invasion underway; D: Invasion completed) 


\section{Cluster and ordination}

In the cluster and ordination analysis, the macrobenthic communities can be classified into three groups (Fig. 3). The results showed macrobenthic communities in patches of no invasion and invasion completed significantly distinguished from other communities (G1 and G3). While in patches of initial invasion and invasion underway, the communities were similar (G2).
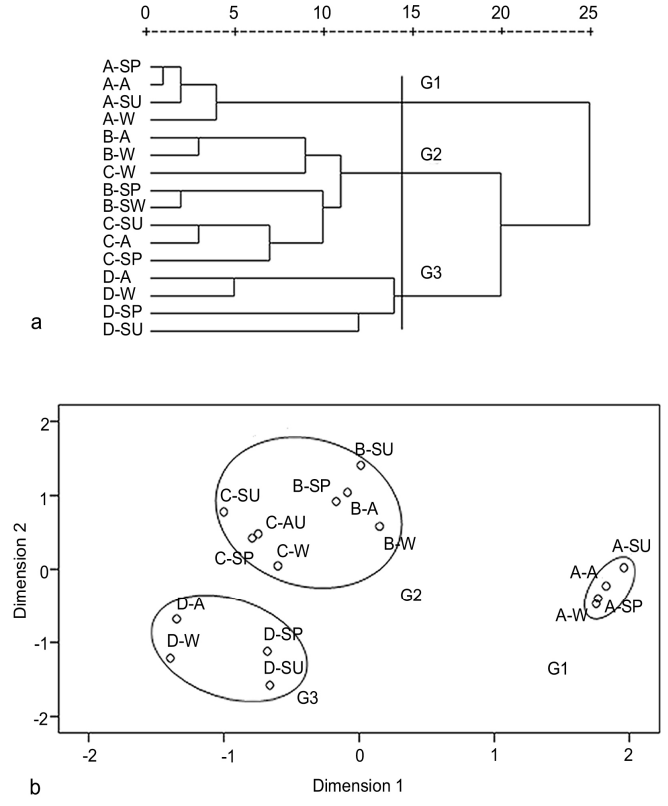

Fig. 3. The rescaled distance hierarchical cluster dendrogram by average linkage between groups (a) and the 2-dimensional nMDS ordinal configuration (stress $=0.069<0.1$, assessment of fit is excellent) (b) (Prefix- A: No invasion; B: Initial invasion; C: Invasion underway; D: Invasion completed; Suffix- SP: Spring; SU: Summer; A: Autumn; W: Winter).

\section{Discussion}

During recent decades, the salt-adapted grasses of the Spartina genus have invaded western Pacific coasts, including those of Japan and China (GREENBERG et al., 2006). Different invasion statuses can lead to alterations in litter production, below-ground biomass, sediment organic content and nutrient cycling (TALLEY; LEVIN, 2001), associated with food availability for benthic fauna (NEIRA et al., 2005), while the trophic function of the wetland is also affected (LEVIN et al., 2006).

It has been reported that the invasive Spartina would decrease the biodiversity level on the tidal flat with a significant effect on benthos (NEIRA et al.,
2006; WANG et al., 2010), but our findings differ in some measure from the conclusions of previous researchers. In this study, the results indicate that the macrobenthic communities had higher species richness and diversity indices in the patch of initial $S$. alterniflora invasion as compared with those of other invasion stages (Fig. 2; Table 2). This phenomenon must result from the habitat changes due to different $S$. alterniflora invasion stages (WANG et al., 2006). During the initial invasion, the environment can offer a greater variety of micro-habitats for benthos as a result of the low density of $S$. alterniflora, however when the roots of $S$. alterniflora harden the sediment and then stems and leaves develop above ground after the initial invasion stage, the habitat changes and is no longer fit for some kinds of benthos, such as species of Bivalvia and Nemertina (NEIRA et al., 2005; 2007; WANG et al., 2010).

The season factor significantly affected macrobenthic communities in this research as was also concluded in some previous studies on macrobenthic communities in temperate and subtropical regions (ZAJAC; WHITLATCH, 1982; LU; WU, 2000), normally the higher abundance and species richness were found in spring/summer, while the lower values occurred in autumn/winter. In our study, we found that the higher abundance, species richness and biodiversity values of macrobenthic communities occurred in summer/autumn in the patches with no invasion or with initial $S$. alterniflora invasion, higher values occurring in spring in the patch with invasion underway, while the higher values occurred in autumn in the patch with $S$. alterniflora invasion complete (Fig. 2; Table 2). The variation of macrobenthic communities between the seasons might be related to the seasonal development of the roots and the seasonal variation of the coverage of $S$. alterniflora (WANG et al., 2006).

In addition to the isolated effects of the individual factors, the interaction between season and invasion stage was an important factor which might be determining the distribution of the macrobenthos. The significant interaction indicated that the macrobenthic communities were also being affected by the changes in the invasion stages, which reinforced the effects of the seasonal changes.

The hierarchical cluster and nMDS have been used to analyze differences in the community structure of macrobenthic fauna in some other similar research projects (LUI et al., 2002; STEFFENS et al., 2006). We found that the hierarchical clustering (Fig. 3a) was well superimposed on nMDS ordinal configuration (stress $=0.069)$ (Fig. 3b). Although there is no strict rule regarding how much stress is tolerable, the rule of thumb is that a value $\leq 0.1$ is excellent (JAWORSKA; CHUPTLOVSKA-ANASTASOVA, 2009). Because of their sedentary life style, the distribution and 
abundance of benthos are particularly sensitive to local environmental conditions; the macrobenthos representing one of the most important permanent resident animal groups in coastal wetlands (LUCKENBACH et al., 1990).

Our results indicate that the macrobenthic community changed significantly in the various habitats in accordance with the sequence of invasion stages of S. alterniflora. The characteristics of the habitats (such as canopy, root development, and sediment) changed according to the different invasion stages and this could affect the availability of macrobenthos niches (NEIRA et al., 2005). And then the significant seasonal variation of the macrobethic community has been presented in our research in such a way as to relate it to the history of $S$. alterniflora (WANG et al., 2006). Our findings can be used to control the S. alterniflora invasion, in association with biodiversity protection on the tidal flats of the western Pacific, where $S$. alterniflora was originally introduced as an ecosystem engineer.

\section{ACKNOWLEDGEMENTS}

We would like to thank HUAN-HUAN LI who participated in the field work. This research was supported by the Natural Science Foundation of Yancheng City (No. YKN2011006), the Zhejiang Provincial Natural Science Foundation of China (No. ZE0204), the Natural Science Foundation of Jiangsu Province (No. BK2011421) and the National Natural Science Foundation of China (No. 31000142).

\section{REFERENCES}

ALPHIN, T. D.; POSEY, M. H. Long-term trends in vegetation dominance and infaunal community composition in created marshes. Wetl. Ecol. Manag., v. 8, p. 317-325, 2000.

BAO, Y. X.; GE, B. M.; ZHENG, X.; CHENG, H. Y.; HU, Y. Z. Seasonal variation of the macrobenthic community at east tidal flat of Lingkun Island, Wenzhou Bay. Acta Hydrobiol. Sinica, v. 31, p. 437-444, 2007. (in Chinese)

BRUSATI, E.; GROSHOLZ, E. D. Native and introduced ecosystem engineers produce contrasting effects on estuarine infaunal communities. Biol. Invasions, v. 8, p. 683-695, 2006.

CLARKE, K. R.; WARWICK, R. M. Change in marine communities: an approach to statistical analysis and interpretation. 2nd ed. Plymouth, UK : Primer-E, Plymouth Marine Laboratory, 2001.

CLEARY, M. B.; PENDALL, E.; EWERS, B. E. Testing sagebrush allometric relationships across three fire chronosequences in Wyoming, USA. J. Arid Environ. v. 72, p. 285-301,2008.

CROOKS, J. A.Characterizing ecosystem-level consequences of biological invasions: the role of ecosystem engineers. Oikos, v. 97, p. 153-166,2002.
DAEHLER, C. C.; STRONG, D. R. Reduced herbivore resistance in introduced smooth cordgrass (Spartina alterniflora) after a century of herbivore-free growth. Oecologia, v. 110, p. 99-108,1997.

DUNNETT, C. W. Pairwise multiple comparisons in the unequal variance case. J. Am. Stat. Assoc., v. 75, p. 796-800,1980.

GE, B.M.; BAO, Y. X.; CHENG, H. Y. Tempo-spatial variation of macrobenthic communities on a tidal flat of Wenzhou Bay, China. Rev. Biol. Mar. Oceanogr., v .46, p. 281-286, 2011.

GOGINA, M; GLOCKZIN, M.; ZETTLER, M. L.Distribution of benthic macrofaunal communities in the western Baltic Sea with regard to near-bottom environmental parameters. 1. Causal analysis. J. Mar. Syst., v. 79, p. 112-123,2010.

GREENBERG, R.; MALDONADO, J. E.; DROEGE, S.; MCDONALD, M. V. Tidal marshes: a global perspective on the evolution and conservation of their terrestrial vertebrates. BioScience,v.56, p. 675-685, 2006.

HEDGE, P.; KRIWOKEN, L. K. Evidence for effects of Spartina anglica invasion on benthic macrofauna in Little Swanport estuary, Tasmania. Austral Ecol.v.25, p. $150-159,2000$.

JAWORSKA, N.; CHUPTLOVSKA-ANASTASOVA, A. A review of multidimensional scaling (MDS) and its utility in various psychological domains. Tutorials Quant. Meth. Psych., v. 5, p. 1-10, 2009.

JONES, C. G.; LAWTON, J. H.; SHACHAK, M. Organisms as ecosystem engineers. Oikos,v.69, p. 373386, 1994.

LEVIN, L. A.; NEIRA, C.; GROSHOLZ, E. D. Invasive cordgrass modifies wetland trophic function. Ecology,v.87, p. 419-432,2006.

LI, Y. B.; LIANG, F. G.; YAN, L. H. Vicissitude and response of exploitation of Spartina alterniflora Loisel in tidal flat of Wenzhou coast. Mar. Environ. Sci.,v.28, p. 324-328,2009. (in Chinese with English abstract)

LU, L.; WU, R. S. S. An experimental study on recolonization and succession of marine macrobenthos in defaunated sediment. Mar. Biol.,v.136, p. 291-302, 2000.

LU, Y. J.; LI, H. L.; WANG, H. C.; ZUO, L. Q. Back silting and regulation of waterway with sand bar in strong tidal estuary. J. o Hyd. Eng.,v.36, p. 1450-1456, 2005. (in Chinese with English abstract)

LUCKENBACH, M. W.; DIAZ, R. J.; ZOBRIST, E. C.; HUTTON, C. H. Evaluation of the benthic resource value of impounded and non-impounded tidal creeks in Virginia, USA. Ocean Coast Manage., v. 14, p. 35-50, 1990

LUI, T. H.; LEE, S. Y.; SADOVY, Y. Macrobenthos of a tidal impoundment at the Mai Po Marshes Nature Reserve, Hong Kong. Hydrobiologia,v.468, 193212,2002.

MARGALEF, D. R. Information theory in ecology. Gen. Syst.,v.3, p. 36-71, 1957.

NEIRA, C.; LEVIN, L. A.; GROSHOLZ, E. D. Benthic macrofaunal communities of three sites in San Francisco Bay invaded by hybrid Spartina, with comparison to uninvaded habitats. Mar. Ecol. Prog. Ser. ,v.292, p. 111-126,2005. 
NEIRA, C.; GROSHOLZ, E. D.; LEVIN, L. A.; BLAKE, R. Mechanisms generating modification of benthos following tidal flat invasion by a Spartina hybrid. Ecol. Appl. ,v.16, p. 1391-1404, 2006.

NEIRA, C.; LEVIN, L. A.; GROSHOLZ, E. D.; MENDOZA, G. Influence of invasive Spartina growth stages on associated macrofaunal communities. Biol. Invasions,v.9, p. 975-993, 2007.

OLBERS, J. M.; CELLIERS, L.; SCHLEYER, M. H Zonation of benthic communities on the subtropical Aliwal Shoal, Durban, KwaZulu-Natal, South Africa. Afr. Zool.,v.44, p. 8-23, 2009.

PENNINGS, S. C.; BERTNESS, M. D. Salt marsh communities. In: BERTNESS, M. D.; GAINES, S. D.; HAY, M. E. (Ed.). Marine community ecology. Sunderland, Ma., : Sinauer Associates, 2001. p. 289-316.

SHANNON, C. E.; WEAVER, W. The mathematical theory of communication. Urbana: University of Illinois Press, 1949.

SIMENSTAD, C. A.; THOM, R. M. Spartina alterniflora (smooth cordgrass) as an invasive halophyte in Pacific Northwest estuaries. Hortus Northwest,v.6, p. 9-12, 3840, 1995.
STEFFENS, M.; PIEPENBURG, D; SCHMID, M. K. Distribution and structure of macrobenthic fauna in the eastern Laptev Sea in relation to environmental factors. Polar Biol. ,v.29, p. 837-848,2006.

TALLEY, T. S.; LEVIN, L. A. Modification of sediments and macrofauna by an invasive marsh plant. Biol. Invasions, v.3, p. 51-68,2001.

WANG, Q.; AN, S. Q.; MA, Z. J.; ZHAO, B.; CHEN, J. K.; LI, B. Invasive Spartina alterniflora: biology, ecology and management. Acta Phytotaxonom. Sinica,v.44, p. 559-588, 2006. (in Chinese with English abstract)

WANG, R.; YUAN, L.; ZHANG, L. Impacts of Spartina alterniflora invasion on the benthic communities of salt marshes in the Yangtze Estuary, China. Ecol. Eng.,v.36, p. 799-806,2010.

ZAJAC, R. N. WHITLATCH, R. B. Responses of estuarine infauna to disturbance. II. Spatial and temporal variation of succession. Mar. Ecol. Prog. Ser., v.10, p. 15-27, 1982.

(Manuscript received 14 May 2012; revised 08 September 2012; accepted 11 September 2012) 